\title{
Quantitative Studies on Regional Differences in Purkinje Cell Dendritic Spines and Parallel Fiber Synaptic Density
}

\author{
H. Heinsen* and Y.L. Heinsen
}

Abteilung Anatomie der RWTH Aachen, Aachen, Bundesrepublik Deutschland

\begin{abstract}
Summary. Volume densities, surface densities, length densities and numerical densities of several structures in the neocerebellar lobule VIa and the archicerebellar lobule $\mathrm{X}$ of six-month old male Han:WIST-rats were estimated by point- and intersection-counting. The volume densities of dendritic spines (ca. 6.5\%), parallel fiber varicosities (ca. $25 \%$ ) and processes of Bergmann glial cells (ca. $21 \%$ ) were similar in the upper third of the molecular layer of lobule VIa and X respectively. The surface density of the spine membrane was $31 \mathrm{~mm}^{2} / \mathrm{mm}^{3}$ in lobule $X$ and $32 \mathrm{~mm}^{2} / \mathrm{mm}^{3}$ in lobule VIa ( $p=0.4375$; paired Pitman permutation test). The length density of dendritic spines varied from 793 meters $/ \mathrm{mm}^{3}$ in lobule VIa to 675 meters $/ \mathrm{mm}^{3}$ in lobule $\mathrm{X}(p=0.0938)$. The mean caliper diameter of parallel fiber-Purkinje cell synapses was estimated by Mayhew's (1979) method and calculated by Cruz-Orive's (1983) computer program. Both tests yielded nearly identical numerical densities of parallel fiber synapses in lobule VIa $\left(6.558 \times 10^{8} / \mathrm{mm}^{3}\right)$ and in lobule X $\left(4.892 \times 10^{8} / \mathrm{mm}^{3} ; p=0.0313\right)$. The area of synaptic apposition relative to the postsynaptic dendritic spine surface was higher in lobule VIa $(13.3 \%)$ than in lobule $\mathrm{X}(10.4 \% ; p=0.0313)$. The data provide electron microscopic evidence of regional differences in spine morphology, which together with different spiny branchlet diameter and numerical density of parallel fiber synapses may be of importance in Purkinje cell physiology.
\end{abstract}

Key words: Cerebellar cortex - Albino rats - Quantitative anatomyPurkinje cells - Spines - Parallel fiber synapses - Regional differences

\section{Introduction}

The dendritic trees of Purkinje cells display their full ramification in a vertical plane at right angles to the longitudinal axis of the cerebellar lobule.

Offprint requests to: Dr. Helmut Heinsen, RWTH Aachen, Abtlg. Anatomie, D-5100 Aachen, Federal Republic of Germany

* Supported by a grant from the „Deutsche Forschungsgemeinschaft" (La 184/7) 
Parallel fibers cross the Purkinje cell dendritic field at rightangles. They run parallel to the longitudinal axis of the lobule. Mathematically, the threedimensional structure of the cerebellar cortex can only be reconstructed by translation in two directions. The architecture of the cerebellar cortex has been designated as a lattice (Braitenberg and Atwood 1958). It is a unique feature of the cerebellar cortex compared with retina, telencephalic cortex, tectum of lower vertebrates, inferior olive and certain invertebrate ganglia. Its design remains invaried in phylogeny (Braitenberg and Atwood 1958). The arrangement of Purkinje cell dendrites and parallel fibers allows maximal convergence and divergence in minimal space (Fox and Barnard 1957; Fox et al. 1964, 1967; Hámori and Szentágothai 1964). The mossy fiber-granule cell-parallel fiber system conveys, together with the climbing fibers, the main afferent inputs to the cerebellar Purkinje cells (Llinás and Hillman 1969). As a general rule, the parallel fiber varicosities make 'en passant' synaptic connections with the dendritic spines of Purkinje cell spiny branchlets (Mugnaini 1972). In glutaraldehyde-osmium fixed tissue the presynaptic vesicles are round and clear, the excitatory synapses belonging to Gray's type 1 (Mugnaini 1972; Palay and Chan-Palay 1974). The total number of the dendritic spines or thorns per Purkinje cell which accept the parallel fibers is species-dependent and, due to methodological difficulties, disputed: monkey 60,000 (Fox and Barnard 1957) and 120,000 (Fox et al. 1964); cat 80,000 (Palkovits et al. 1971); rat 16,000 to 18,000 (Palay and Chan-Palay 1974) and 54,000 (Hillman and Chen 1981). The dendritic spines are attached by a thin stalk to the parent dendrite. Physiologically, a thin stalk offers a great ohmic resistance (Merril and Wall 1972), isolates dendritic spine synapses from other synapses in the neuron (Diamond et al. 1970) and may change the relative weights of synaptic input from different afferent sources (Rall 1970). The number of parallel fiber - Purkinje cell

Fig. 1. Longitudinal section through spiny branchlet $(s b)$ in the upper molecular layer of lobule $\mathrm{X}$. Note the diameter of the spiny branchlet, the density of long mitochondria and parallel microtubules. Only few spines emanate from this terminal dendrite. $(g l$ Process of Bergmann glial cell. Bar $1 \mu$. Inset $a$. Spine from lobule $\mathrm{X}$ with slightly thickened head bearing a Gray type 1 asymmetrical synapse with parallel fiber varicosity. The stalk is thick and hardly delimited from the head. Bar $0.5 \mu$. Inset b. Silver impregnation after Bubenaite (Romeis 1948). Glutaraldehyde-paraformaldehyde perfusion (Palay and Chan-Palay 1974), $60 \mu$ Vibratomesection. Original color of impregnation deep red. Note diameter, length and density of the spiny branchlets and the number of spines on their surface and compare with the electron micrograph. Bar $2 \mu$

Fig. 2. Longitudinal section through spiny branchlet $(s b)$ in the upper third of the molecular layer of lobule VIa. The diameter is larger than in Fig. 1. The branchlet has numerous dendritic spines which are club-shaped and connected by a thin stalk to the parent spiny branchlet. $(g l)$ process of Bergmann glial cell. Bar $1 \mu$. Inset $a$. Longitudinal section through spine with "swollen" head and thin stalk. Asymmetrical type 2 (Gray) synapse with parallel fiber varicosity. Bar $0.5 \mu$. Inset $b$. Silver impregnation after Bubenaite (Romeis 1948). Glutaraldehydeparaformaldehyde perfusion, $60 \mu$ Vibratom-section. Original color deep red. Spiny branchlets are thicker and branch frequently, the density of spines on their surface is extremely high and in the light microscope single spines can hardly be counted. Bar $2 \mu$ 

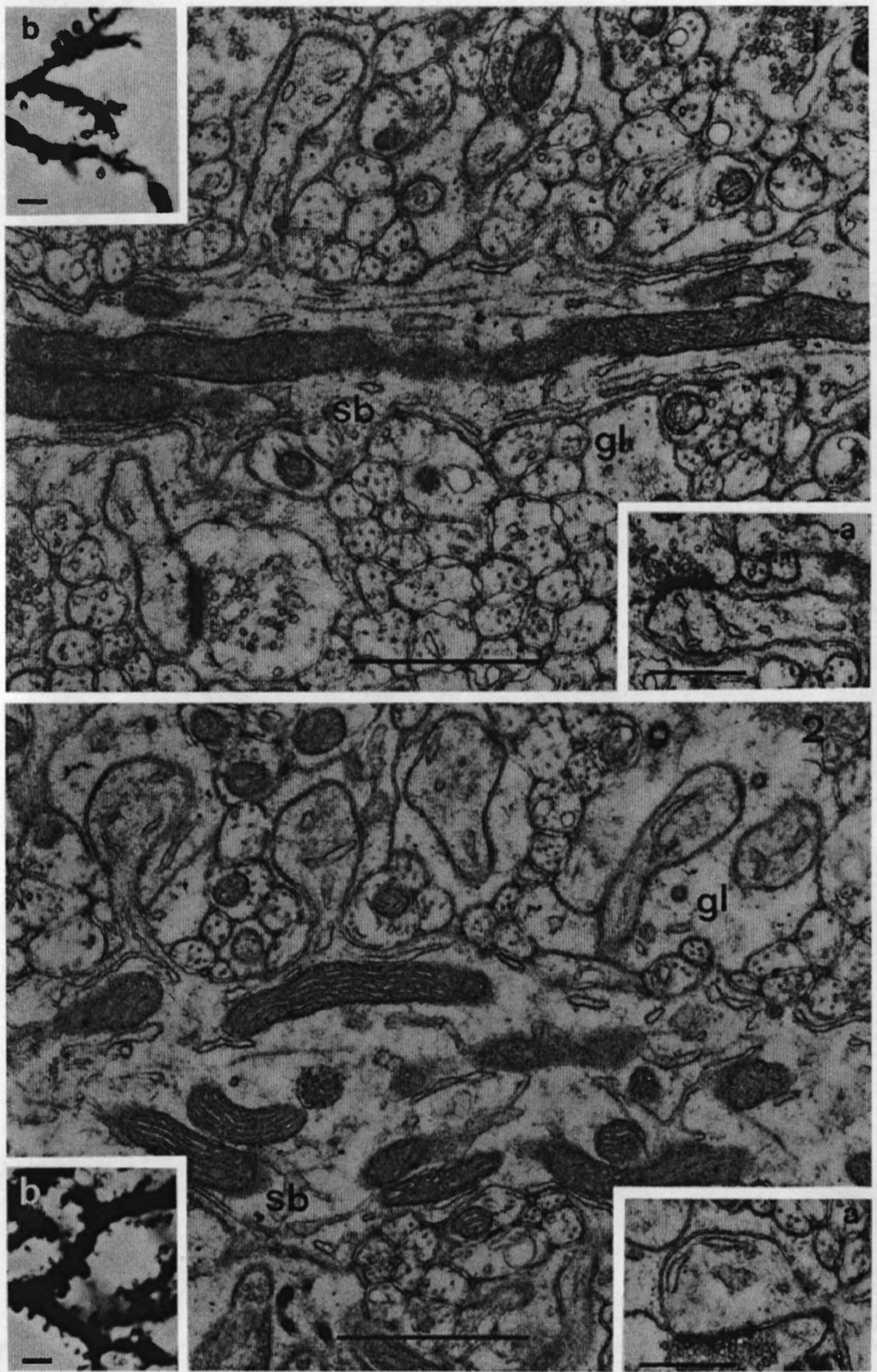
synapses has been estimated to be in the range of $5 \times 10^{8} / \mathrm{mm}^{3}$ in lobules V-VI (Robain et al. 1981) and $8 \times 10^{8} / \mathrm{mm}^{3}$ in lobules IV-VI (Ruela et al. 1980).

The quantitative investigations mentioned above were performed on different lobules of the cerebellar cortex, and most authors did not consider regional differences (for further literature see Müller and Heinsen 1984). During evolution most changes occurred in the mossy fiber - granule cell input (Llinás and Hillman 1969). Therefore, quantitative studies on regional differences in the parallel fiber-Purkinje cell system are warrantable in order to provide data for the understanding of the physiology of the cerebellar cortex.

\section{Materials and Methods}

Six male SPF-Hannover-Wistar rats 6 months old (Han:WIST; retired breeders; Zentralinstitut für Versuchstierzucht; Hannover, FRG) were anaesthetized with Nembutal ${ }^{\otimes}$ and fixed by transcardiac perfusion in a phosphate-buffered $1 \%$ glutaraldehyde $-1 \%$ formaldehyde solution according to Palay and Chan-Palay 1974). The vermes were cut medio-sagitally by means of two parallel razor blades and embedded in Araldite (Palay and Chan-Palay 1974). Trimmed blocks containing tissue fragments of lobule VIa and X (Larsell 1952) were cut at five different levels, each succeeding depth level about $50 \mu \mathrm{m}$ deeper than the preceding one. Ultrathin sections from the five depth-levels were mounted onto Formvar ${ }^{-}$-coated single-hole slot grids S2 $\times 1$ (Polysciences). Ten negatives of the upper molecular layer were photographed at an initial magnification of $6,800 \times$ for each ultrathin section with a Philips EM 300 electron microscope. Fifty $18 \times 24 \mathrm{~cm}$ photographic prints per region and animal were analyzed by stereological methods. Transparent folia with a simple square lattice test system (Weibel 1979; $\mathrm{d}=18 \mathrm{~mm}, P_{T}=77$ ) were laid over the $18 \times 24 \mathrm{~cm}$ photographic prints. The final magnification (ca. $22,200 \times$ ) was regularly controlled with a grating replica, spacing of $2160 \mathrm{lines} / \mathrm{mm}$. The volume fraction $\left(V_{v}\right)$ of Purkinje cell dendritic spines, parallel fiber varicosities containing at least two or more unequivocally recognizable synaptic vesicles and the processes of Bergmann glial cells were estimated with point-counting methods. Together, these structures contribute about $50 \%$ of the volume of the upper molecular layer. Parallel fibers without varicosities, processes of stellate cells, pericytes and microglial cells constitute the other $50 \%$ of the tissue mass, but were disregarded in the present quantitative study. We wish to emphasize the fact that we have chosen only areas of the molecular layer free from perikarya of stellate cells, microglial cells or vascular profiles. In this respect, our sampling procedure is a "stepwise" one, pertaining only to the neuropil of the upper molecular layer as reference volume (Weibel 1979).

By means of the square lattice system and according to the propositions of Mayhew (1979) the surface density of Purkinje cell spines (thorns) $\left(S_{\mathrm{v}}\right)$, their length density $\left(L_{\mathrm{v}}\right)$ and the ratio of the surface of the dendritic spine plasmalemma to the surface occupied by parallel fiber synaptic appositions $\left(I_{\text {syn }} / I_{\text {dend }}\right)$, the mean caliper diameter of the 'actual' synaptic discs $\left(\bar{D}_{s y n}\right)$ and the numerical density of parallel fiber-Purkinje cell synapses $/ \mathrm{mm}^{3}\left(N_{\mathrm{v}}\right)$ in the upper third of the molecular layer of lobule VIa and X were estimated. Since the mean synapse diameter is small in relation to the section thickness, the raw data were corrected for overestimation due to section thickness. Section thickness was estimated with Small's method (Weibel 1979). Overestimations of synaptic profiles through thin electron microscopic sections are a result of overprojection (Holme's effect). On the other hand, not every tangentially cut small synaptic profile may be recognized on electron-microscopic prints (truncation effect, Cruz-Orive 1983). Cruz-Orive (1983) developed a computer program to elicit a particle size distribution from the observed profile distribution. His unfolding algorithm copes with the section thickness effect and truncation. The histogram of the synaptic profile distribution was constructed by means of a MOP AM 03 (Kontron). In convex synaptic profiles, only the minimal distance between both extremities of the postsynaptic thickening were measured 


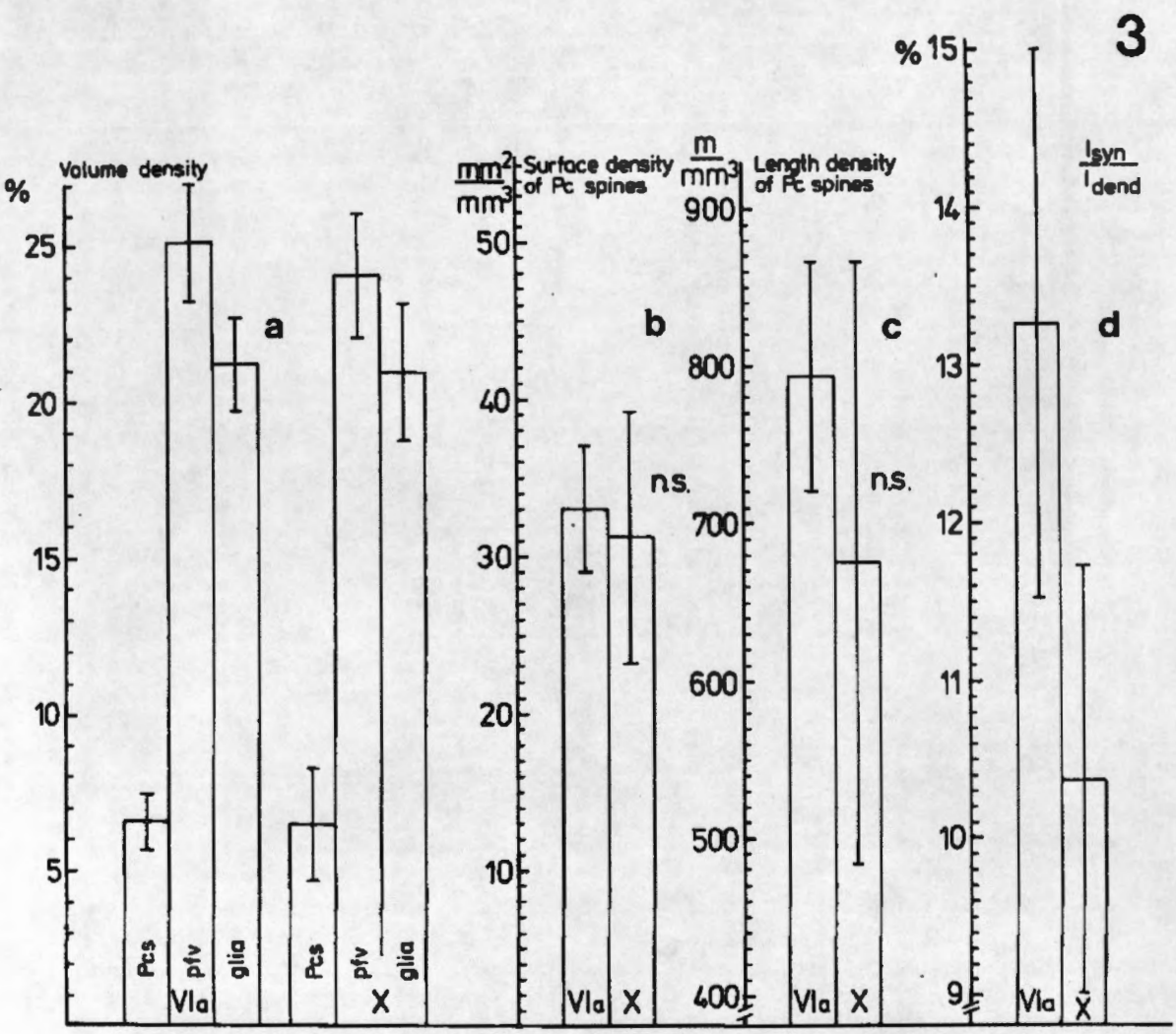

Fig. 3. a Volume density $\left(V_{v}\right)$ of Purkinje cell dendritic spines $(P c s)$, parallel fiber varicosities (pfv) and Bergmann glia ( $g$ lia) in the upper molecular layer of lobule VI a and X. Means and standard deviations of the means. b Surface of dendritic spines per unit volume of the neuropil of the upper molecular layer expressed as surface density $\left(S_{\mathrm{v}}\right)$. Means and standard deviations of the means $(p=0.4375$; paired Pitman permutation test). $\mathrm{c}$ Total length of dendritic spines per unit volume of the neuropil of the upper molecular layer (length density, $L_{v}$ ). The dimensions are meter (!) per $\mathrm{mm}^{3}$. Means and standard deviations of the means $(p=$ 0.0938). d Relative surface of dendritic spine plasmalemma occupied by synaptic apposition with parallel fiber varicosities $\left(I_{\mathrm{ayn}} / I_{\text {dend }}\right)$. Since the average diameter of the synaptic discs is similar in both cerebellar regions (Fig. 4a), either the number of discs per spine is higher in lobule VIa or the surface and possibly the shape of spines are lower and different in lobule VI as compared with lobule X $(p=0.0313)$

and classified into 15 classes with a class interval of $2.0 \mathrm{~mm}$ (ca. $90 \mathrm{~nm}$ at $22,200 \times$ magnification).

The surface density of Purkinje cell dendritic spines, their length density, $I_{\text {zyp }} / I_{\text {dend }}$ and the numerical density of the synaptic profiles $\left(N_{\mathrm{V}}\right.$, Mayhew's method) were tested with a paired Pitman permutation-test (Witting and Nölle 1970) at the „Abteilung für Medizinische Dokumentation und Statistik der RWTH Aachen". The p-values for the two-sided tests are given in brackets. Since the number of animals was too low, the other quantitative parameters were not tested statistically.

Two "hemivermes" were treated with a modified Golgi method (Bubenaite; Romeis 1948) and sectioned with a Vibratome at $60 \mu \mathrm{m}$.

\section{Results}

In mediosagittal sections through the cerebellar cortex of lobules VIa and $\mathrm{X}$, round, densely packed profiles of cross-sectioned parallel fibers were the most frequently observed structures. Longitudinally or obliquely cut 


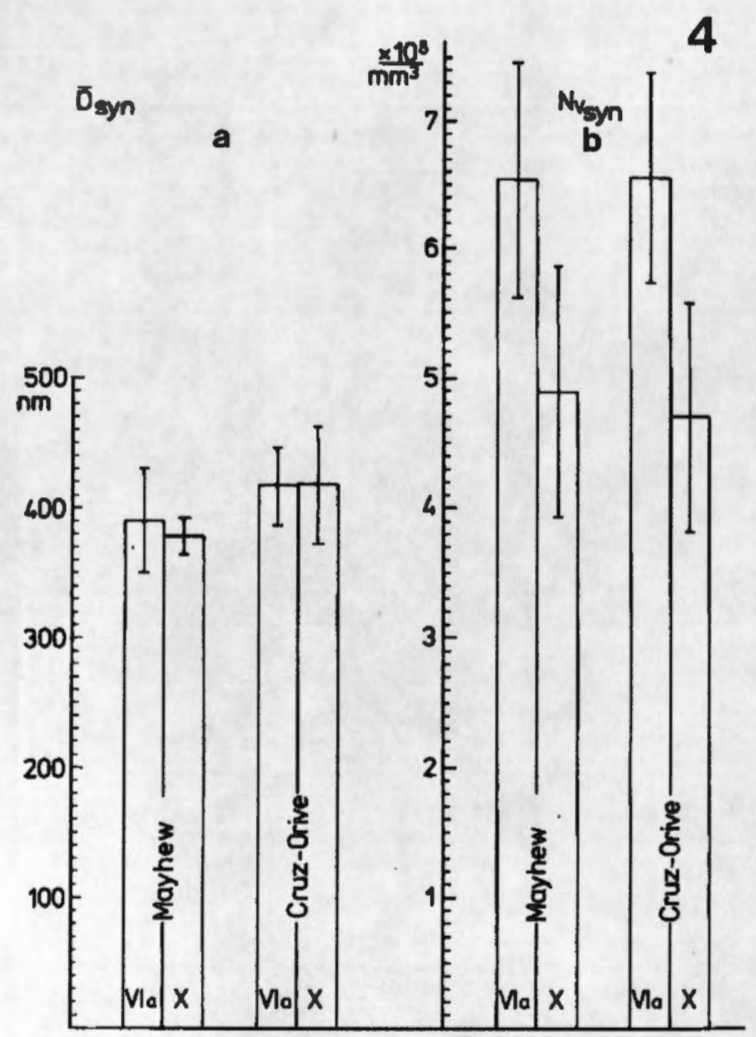

Fig. 4. a Mean caliper diameter estimated by Mayhew's (1979) intersection counting procedure and by classification of profile length with a MOP AM O3 and reconstruction with a computer program of Cruz-Orive (1983). The mean caliper diameter is higher by the factor $4 / \pi$ than the mean trace length given by other authors (c.f. Palay and Chan-Palay 1974). Means and standard deviations of the means.

b Number of synapses per $\mathrm{mm}^{3}$ neuropil $\left(N_{\mathrm{V}}\right)$ in the upper molecular layer estimated with the methods of Mayhew (1979) and calculated with a computer program of Cruz-Orive (1983). The numerical density of synapses is ca. $33 \%$ higher in lobule VI a $(p=0.0313$;

Mayhew's method; Cruz-Orive's method not tested statistically)

profiles from dendrites or axons of stellate cells were far less frequently encountered. Together with the processes of microglial cells, these structures constituted about $50 \%$ of the total neuropil of the upper molecular layer.

In the vicinity of Purkinje cell spiny branchlets, the tightly packed formation of parallel fibers was disaggregated by intervening cytoplasmic processes of Bergmann glial cells. The processes of Bergmann glial cells partly invested the spiny branchlets of Purkinje cells (Figs. 1, 2). Streaming away from the dendrites of Purkinje cells, glial processes surrounded both dendritic spines and single parallel fibers, insulating the latter from adjacent parallel fiber bundles. From favourable longitudinal sections through spiny branchlets we concluded that a fair number of dendritic spines crowded the surface of the branchlets (Fig. 2) The number of dendritic spine profiles was higher in lobule VIa, whereas spiny branchlets in lobule X were generally thinner, longer and bestowed with less dendritic spines (Fig. 1). The arrangement of microtubules in spiny branchlets of lobule VIa appeared less regular (Fig. 2). Frequently, extremely long mitochondria were compressed into the spiny branchlets of Purkinje cells of lobule X (Fig. 1).

In spite of the numerous spines covering the surface of spiny branchlets, the volume density of the former was rather low with about $6.5 \%$ in both lobules (Fig. 3a, Pcs).

Parallel fiber varicosities occupied $24 \%$ of the neuropil volume in lobule $\mathrm{X}$ and $25 \%$ in lobule VIa (Fig. 3, a; pfv). The volume density of the glial investment was slightly lower than the relative volume of the parallel fiber 
varicosities (ca. $21 \%$ in both lobules; Fig. 3 a, glia). Despite their minute dimensions, the surface density of the spine membranes was $33 \mathrm{~mm}^{2} / \mathrm{mm}^{3}$ in lobule VIa and $31 \mathrm{~mm}^{2} / \mathrm{mm}^{3}$ in lobule $\mathrm{X}(p=0.4375$; Fig. $3 \mathrm{~b})$. Even more impressive was the total length of Purkinje cell dendritic spines per $\mathrm{mm}^{3}$ molecular layer (Fig. 3c). Arranged in one single line, the total length of the dendritic spines would be 793 meters in lobule VIa and ca. 675 meters in lobule $\mathrm{X}(p=0.0938)$.

The mean caliper diameter of the synaptic discs was 380 to $420 \mathrm{~nm}$ (Fig. 4a). Mayhew's method yielded lower and Cruz-Orives computer program higher means (Fig. 4a). Regional differences in mean caliper diameter apparently did not exist.

The numerical density of parallel fiber synapses was higher in lobule VIa $\left(6.558 \times 10^{8} / \mathrm{mm}^{3}\right)$ and ca. $33 \%$ lower in lobule X $\left(4.892 \times 10^{8} / \mathrm{mm}^{3}\right.$; Mayhew's methods; $p=0.0312$ ). $N_{\mathrm{v}}$-estimations yielded nearly identical results with both methods (Fig. $4 \mathrm{~b}$ ).

The synaptic discs in lobule VIa occupied $13.4 \%$ of the spine surface and $10.4 \%$ of the surface (Fig. $3 \mathrm{~d})$ in spines of lobule X $(p=0.0312)$.

\section{Discussion}

The numerical density of parallel fiber synapses in the neocerebellar lobule VIa (Larsell 1952) was $33 \%$ higher than in the archicerebellar lobule X (Fig. 4b). Two different methods (Mayhew 1979; Cruz-Orive 1983) yielded nearly identical results (Fig. 4b). Overprojection and truncation (for a review see Cruz-Orive 1983) apparently balance each other out and Mayhew's method (1979) for estimating synapse density has proved to be a simple and fast procedure.

According to Altman (1982) the cerebellar molecular layer is hierarchically organized: mossy fibers from the spinal cord and the external cuneate nucleus terminate via parallel fibers from deep granule cells on Purkinje cell dendrites in the lower molecular layer. Cerebral afferents are relayed in the pontine nuclei and establish synaptic contacts via superficial granule cells in the upper molecular layer. The higher numerical density of parallel fiber synapses in the upper third of the molecular layer in the neocerebellar lobule VIa confirms Altman's (1982) hypothesis.

We concluded from our silver impregnations that spiny branchlets in lobule $\mathrm{X}$ were longer and thinner, but their overall density was lower, than in lobule VIa (Figs. 1 b, 2b). Similar regional differences were reported by Floeter and Greenough (1979) in the monkey. The question arises which mechanisms are responsible for the enhanced numerical density of parallel fiber synapses. Several factors can be considered including enhanced granule cell density, longer parallel fibers with a higher number of varicosities in lobule VIa, reduced numerical density of Purkinje cells in neocerebellar lobules (Heinsen and Heinsen 1983) and multiple innervation of Purkinje cell dendritic spines by two or more parallel fibers per spine. We can rule out the last possibility, since the incidence of multiple innervation of an individual spine was rather low in both lobules (ca. $5 \%$ ). 
In addition to a higher number of synaptic sites, the morphology of the dendritic spines exhibited regional differences. The spines of lobule VIa were rather club-shaped. The large round head was attached with a thin neck to the spiny branchlets (Fig. 2, inset a). The spines of lobule $X$ were longer, the head less swollen, the stalk thicker and consequently the transition between head and stalk less pronounced (Fig. 1, inset a). The spines of lobule X resembled thorns or fingers (Spaček and Hartmann 1983) rather than clubs. An additional evidence for shape differences in spine morphology can be deduced from the quantitative results. Volume density divided by length density yields the average profile area of spines. Volume density in lobule VIa was $0.065 \mathrm{~mm}^{3} / \mathrm{mm}^{3}(6.5 \%)$, length density $793 \times 10^{3} \mathrm{~mm} /$ $\mathrm{mm}^{3}$ and $0.065 \mathrm{~mm}^{3} / \mathrm{mm}^{3}$ and $675 \times 10^{3} \mathrm{~mm} / \mathrm{mm}^{3}$ in lobule $X$. The average profile area in lobule VIa would be $8.2 \times 10^{-2} \mu \mathrm{m}^{2}$ and $9.63 \times 10^{-2} \mu \mathrm{m}^{2}$ in lobule X. By means of the circle formula, the average diameter can be calculated as $0.32 \mu \mathrm{m}$ in lobule VIa and $0.35 \mu \mathrm{m}$ in lobule X. These differences would imply that either (i) spines in lobule $\mathrm{X}$ are longer and thicker or (ii) if the spine head diameter in lobule VIa is considerably larger than in lobule $\mathrm{X}$, as the Em photographs suggested, then the stalk of spines in lobule VIa must be compensatorily extremely thin.

At variance with Spaček and Hartmann (1983), we found regional differences in the ratio synaptic apposition area to dendritic spine surface (Fig. 3d). In lobule VIa, our means were twofold higher than the data of Spaček and Hartmann (1983). High-voltage electron microscopic investigations on silver-impregnated spines (Palay and Chan-Palay 1974) will perhaps demonstrate actual regional differences in spine morphology and synaptic sites.

From the quantitative differences in number and in shape of spines as well as in parallel fiber density, differences in the physiology of information integration in Purkinje cells in lobules VIa and X can be anticipated. Pellegrino and Altman (1979) suggested that in the apical domain of Purkinje cells, coordination of action takes place. High synaptic density of parallel fiber synapses, together with thick and numerous spiny branchlets and spines with extremely thin stalks, would explain the very large logical capacities of Purkinje cells in lobule VIa (Shepherd 1974). Changes in spine shape tending towards swollen head and thin stalk are concomitant to the effects of enhanced presynaptic stimulation (Van Harreveld and Fifková 1975), and long thin spines are discussed as possible pathogenetic factors in mental diseases (Marin-Padilla 1974; Purpura 1974). The Purkinje cell spines serve as a current-injecting mechanism and spike-blocking device (Llinás and Hillman 1969). From our quantitative data, regional differences in the dendritic electrotonus are likely and some of the individual firing properties of Purkinje cells (Llinás and Sugimori 1980) can perhaps be explained by morphological differences.

Differences in the numerical density of parallel fiber synapses, in the relative surface of the synaptic apposition zone to the postsynaptic surface and in spine morphology may represent some mechanisms of evolution in a rather rigid lattice structure of the cerebellar cortex. 
Acknowledgements. The authors thank Dr. L.M. Cruz-Orive (University of Bern, Switzerland) for giving us a computer program for the particle unfolding procedure and Dr. G. Giani (Abteilung Medizinische Dokumentation und Statistik der RWTH Aachen) for the statistical tests and comments, Mrs. G. Lange for technical, Mrs. G. Bock for photographic assistance, Mr. W. Graulich for the diagrams and Mrs. G. Mathieu for typing the manuscript.

\section{References}

Altman J (1982) Morphological development of the rat cerebellum and some of its mechanisms. In: Palay SL, Chan-Palay V (eds) The cerebellum. New Vistas. Exp Brain Res Suppl 6, pp 8-49. Springer, Berlin-Heidelberg-New York

Braitenberg V, Atwood RP (1958) Morphological observations on the cerebellar cortex. J Comp Neurol 109:1-33

Cruz-Orive LM (1983) Distribution-free estimation of sphere size distributions from slabs showing overprojection and truncation, with a review of previous methods. J Microsc 131:265-290

Diamond J, Gray EG, Yasargil GM (1970) The function of the dendritic spine: an hypothesis. In: Andersen P, Jansen JKS (eds) Excitatory synaptic mechanisms. Scandinavian University Books Oslo, pp 213-222

Floeter MK, Greenough WT (1979) Cerebellar plasticity: Modification of Purkinje cell structure by differential rearing in monkey. Science 206:227-229

Fox CA, Barnard JW (1957) A quantitative study of the Purkinje cell dendritic branchlets and their relationship to afferent fibres. J Anat 91:299-313

Fox CA, Siegesmund KA, Dutta CR (1964) The Purkinje cell dendritic branchlets and their relation with the parallel fibers: light and electron microscopic observations. In: Cohen M, Snider RS (eds) Morphological and biochemical correlates of neural activity. Harper and Row, New York, pp 112-141

Fox CA, Hillman DE, Siegesmund KA, Dutta CR (1967) The primate cerebellar cortex: a Golgi and electron microscopic study. Progr Brain Res 25:174-225

Hámori J, Szentágothai J (1964) The crossing over in synapse. An electron microscopic study of the molecular layer in the cerebellar cortex. Acta Biol Acad Sci Hung 15:95-117

Heinsen YL, Heinsen H (1983) Regionale Unterschiede der numerischen Purkinjezelldichte im Kleinhirn von Albinoratten zweier Stämme. Acta Anat 116:276-284

Hillman DE, Chen S (1981) Plasticity of synaptic size with constancy of total synaptic contact area on Purkinje cells in the cerebellum. Prog Clin Biol Res 59:229-245

Larsell $O$ (1952) The morphogenesis and adult pattern of the lobules and fissures of the cerebellum of the white rat. J Comp Neurol 97:281-356

Llinás R, Hillman DE (1969) Physiological and morphological organization of the cerebellar circuits in various vertebrates. In: Llinás RR (ed) Neurobiology of cerebellar evolution and development. American Medical Association Chicago, pp 43-73

Llinás R, Sugimori M (1980) Electrophysiological properties of in vitro Purkinje cell somata in mammalian cerebellar slices. J Physiol 305:171-196

Marin-Padilla M (1974) Structural organization of the cerebral cortex (motor area) in human chromosomal aberrations. A Golgi study. I.D. (13-15) trisomy, Patau syndrome. Brain Res 66:375-391

Mayhew TM (1979) Stereological approach to the study of synapse morphometry with particular regard to estimating number in a volume and on a surface. J Neurocytol 8:121-138

Merril EG, Wall PD (1972) Factors forming the edge of a receptive field: the presence of relatively ineffective afferent terminals. J Physiol (London) 226:825-846

Müller U, Heinsen H (1984) Regional differences in the ultrastructure of Purkinje cells. Cell Tissue Res (in press)

Mugnaini E (1972) The histology and cytology of the cerebellar cortex. In: Larsell O, Jansen J (eds) The comparative anatomy and histology of the cerebellum: The human cerebellum, cerebellar connections and cerebellar cortex. University of Minnesota Press Minneapolis, pp 201-265

Palay SL, Chan-Palay V (1974) Cerebellar cortex. Springer, Berlin-Heidelberg-New York 
Palkovits M, Magyar P, Szentágothai J (1971) Quantitative histological analysis of the cerebellar cortex in the cat. III. Structural organization of the molecular layer. Brain Res 34:1-18

Pellegrino L, Altman J (1979) Effects of differential interference with postnatal cerebellar neurogenesis on motor performance, activity level, and maze learning of rats. A developmental study. J Comp Physiol Psychol 93:1-33

Purpura DP (1974) Dendritic spine "dysgenesis" and mental retardation. Science 186:1126-1128

Rall W (1970) Cable properties of dendrites and effects of synaptic location. In: Andersen P, Jansen JKS (eds) Excitatory synaptic mechanisms. Universitetsforlaget, Oslo, Bergen, Tromsö, pp 175-187

Robain O, Bideau I, Farkas E (1981) Developmental changes of synapses in the cerebellar cortex of the rat. A quantitative analysis. Brain Res 206:1-8

Romeis B (1948) Mikroskopische Technik. Oldenbourg München

Ruela C, Matos-Lima L, Sobrinho-Simoes MA, Paula-Barbosa MM (1980) Comparative morphometric study of cerebellar neurons. II. Purkinje cells. Acta Anat 106:270-275

Shepherd GM (1974) The synaptic organization of the brain. An introduction. Oxford University Press New York

Spacek J, Hartmann M (1983) Three-dimensional analysis of dendritic spines. I. Quantitative observations related to dendritic spine and synaptic morphology in cerebral and cerebellar cortices. Anat Embryol 167:289-310

Van Harreveld A, Fifková E (1975) Swelling of dendritic spines in the fascia dentata after stimulation of perforant fibers as mechanism of posttetanic potentiation. Exp Neurol 49:736-749

Weibel ER (1979) Stereological methods, Vol 1. Academic Press London-New York-TorontoSydney-San Francisco

Witting H, Nölle G (1970) Angewandte mathematische Statistik Teubner Stuttgart

Accepted September 9, 1983 